\title{
MEDIA SOSIAL DAN PERKEMBANGAN KOMUNIKASI KORPORAT
}

\author{
Rina Juwita \\ Program Studi Ilmu Komunikasi, Fakultas Ilmu Sosial dan Ilmu Politik, Universitas Mulawarman \\ Samarinda, Kalimantan Timur 75119 \\ No. Telp./HP: 08115551704 \\ E-mail: rinajuwita1704@gmail.com
}

Naskah diterima tanggal 21 Januari 2017, direvisi tanggal 29 Maret 2017, disetujui tanggal 19 April 2017

\section{SOCIAL MEDIA AND DEVELOPMENT OF CORPORATE COMMUNICATIONS}

\begin{abstract}
The presence of social media has changed the corporate communications and quickly revolutionize how public relations campaign or program. Compared to the traditional way which rely merely on pure output, the social media has forced the corporate communications to switch on the dialogue process in which all stakeholders, where is not just the company that has the power to circulate the message. Social media is a revolutionary communication tool that changed quickly how the public relations practice becomes an integral part of corporate communications for many companies and offers new options for PR practitioners in every aspect of the communication process which is executed. By using critical analysis and interpretative approach, this article attempts to compare traditional $P R$ with the modern one that integrates social media, and through this comparison analyses the changes that occur in the company, so it might project what happens with the corporate communications practice in the future.
\end{abstract}

Keywords: social media, corporate communication, public relations.

\begin{abstract}
Abstrak. Kehadiran media sosial telah mengubah aktivitas komunikasi korporat dan dengan cepat merevolusi bagaimana kampanye atau program public relations $(P R)$ berjalan. Jika dibandingkan dengan cara tradisional yang mengandalkan pada output murni, media sosial memaksa komunikasi korporat beralih pada proses dialog di mana para pemangku kepentingan, dan bukan hanya perusahaan sama-sama memiliki kekuasaan terhadap pesan yang beredar. Artikel ini membahas bagaimana media sosial merupakan alat komunikasi revolusioner yang mengubah secara cepat praktik PR menjadi bagian integral dari komunikasi korporat bagi sejumlah perusahaan dan menawarkan pilihan baru bagi para praktisi PR pada setiap aspek proses komunikasi yang dilakukan. Dengan menggunakan pendekatan analisis kritis dan interpretatif, artikel ini mencoba membandingkan PR tradisional dengan PR modern pengguna media sosial, dan melalui perbandingan tersebut menganalisis perubahan yang terjadi dalam perusahaan, sehingga dapat mencoba memroyeksikan apa yang terjadi dengan praktik komunikasi korporat di masa mendatang.
\end{abstract}

Kata kunci: media sosial, komunikasi korporat, public relations. 


\section{PENDAHULUAN}

Media sosial telah membawa perubahan yang luar biasa terhadap praktik komunikasi korporat. Pemasaran media sosial memungkinkan perusahaan untuk berkomunikasi secara langsung dan cepat dengan para pemangku kepentingannya, yang menandai adanya peralihan dari komunikasi korporat satu arah yang bersifat tradisional menjadi proses dialog yang bersifat luas antara perusahaan dengan konsumennya. Perusahaan bisa menggunakan media sosial untuk berbagi informasi, pesan, pencapaian, dan sebagainya yang dimiliki oleh perusahaan. Hal ini menjadi penting untuk diteliti mengingat di masa sekarang ini perusahaan tidak bisa melepaskan diri dari sorotan publik dan harus berinteraksi secara sosial dengan intensitas lebih tinggi demi menjaga eksistensinya. Dengan kata lain, media sosial digunakan sebagai sarana penting bagi strategi komunikasi korporat. Kemajuan media interaktif digital telah membawa struktur komunikasi baru sehingga penting bagi para praktisi dan akademisi komunikasi korporat untuk memahami perubahan yang disebabkan oleh perkembangan tersebut. Bersatunya komunikasi dan teknologi menawarkan praktisi PR peluang untuk membentuk kinerja ke arah yang lebih strategis. Karena komunikasi korporat yang tidak tepat bisa memberikan pengaruh negatif terhadap persepsi yang dimiliki oleh konsumen dalam sebuah perusahaan.

Media sosial merupakan salah satu aktivitas online favorit yang digunakan oleh publik hampir setiap hari. Menurut artikel yang ditulis oleh Davidson pada tahun 2015 lalu, pengguna internet menghabiskan sekitar satu jam 40 menit perhari di situs sosial, jika dibandingkan dengan satu:empat waktu yang digunakan untuk membaca $e$-mail yang merupakan aktivitas umum jika berkaitan dengan internet (Davidson, 2015). Laporan yang pernah dikeluarkan oleh Global Web Index pada tahun 2015 lalu mengenai trend terbaru berkenaan dengan jejaring sosial menemukan bahwa setiap empat menit yang dihabiskan seseorang di internet digunakan untuk mengakses jejaring sosial, seiring dengan peningkatan penggunaan internet di telepon genggam. Facebook sendiri merupakan media sosial yang memiliki pengguna paling tinggi dan lebih dari $50 \%$ penggunanya selalu mengunjungi aplikasi ini hampir setiap hari. Laporan tersebut juga menemukan bahwa kebanyakan masyarakat saat ini memiliki kurang lebih lima akun media sosial (Rohampton, 2017), di mana laporan lainnya menyatakan bahwa jejaring sosial merupakan aktivitas yang paling banyak menghabiskan waktu pengguna internet di masa sekarang ini.

Pemasaran media sosial sendiri merupakan istilah payung di mana termasuk di dalamnya penggunaan media sosial untuk penjualan, pemasaran, pelayanan konsumen, dan PR yang mengindikasikan adanya konvergensi berbagai divisi di dalam perusahaan yang terpisah secara tradisional. Media sosial sendiri terdiri dari teknologi, praktik, atau komunitas online yang digunakan masyarakat untuk menghasilkan konten tertentu atau berbagi opini, pemahaman, pengalaman, dan perspektif antara satu sama lain (Cohen dalam Patrut \& Patrut, 2013). Contohnya, blog (seperti Blogger, Wordpress, dan Multiply), intranet, podcast, video sharing (seperti YouTube, Vimeo, dan Mediafire), photo sharing (seperti flickr, photobucket, dan instragram), jejaring sosial (seperti facebook, myspace, dan linkedln), wiki (seperti wikipedia, wikidot, dan wikihow), situs game, dunia virtual (seperti secondLife dan IMVU), mikro-blogging (seperti twitter), video-conference chatting pesan instan, sistem acara/kalender sosial (seperti eventful dan localist), dan situs kumpulan berita. Dalam dekade terakhir teknologi tersebut meningkat popularitas dan keberadaanya, serta digunakan oleh para praktisi PR untuk melanggengkan industri komunikasi korporat yang terus berubah. Meskipun media sosial merepresentasikan ragam teknologi yang berbeda-beda, namun 
dalam artikel ini media sosial hanya akan disebut sebagai suatu objek yang bersifat tunggal.

Dalam dunia korporasi saat ini, keberhasilan atau kegagalan suatu perusahaan sangatlah bergantung pada persepsi publik. Opini para pemangku kepentingan kunci perusahaan; seperti pemegang saham, investor, konsumen, pegawai atau masyarakat di mana perusahaan berada merupakan hal yang krusial bagi keberhasilan jangka panjang perusahaan sehingga harus diperhatikan oleh para eksekutif perusahaan. Media sosial memberikan peluang bagi pelaksanaan komunikasi korporat yang di abad sebelumnya dianggap tidak cukup masuk akal untuk dilakukan.

PR dalam konteks tradisional dianggap banyak pihak sebagai 'smoke and mirrors,' yang memberikan pesan yang bersifat semu yang diciptakan oleh 'the spin doctors' (Spin Doctors menurut Thesaurus adalah praktisi PR yang bertugas untuk mencegal publisitas negatif dengan memublikasikan interpretasi yang dianggap menguntungkan akan perkataan dan tindakan sebuah perusahaan atau kelompok politik atau publik figur tertentu (Dilenschneider, 1998). Dikarenakan hal tersebut, banyak orang kemudian menjadi tidak percaya terhadap media (sarana tradisional yang digunakan untuk mengevaluasi suatu industri), dan lebih menaruh kepercayaan terhadap opini kelompok peernya yang memiliki akses terhadap situs media sosial (Michel, Ruggiero \& Yang, 2016). Media sosial tidak hanya menawarkan kesempatan bagi komunikasi korporat yang bersifat langsung dan cepat, tetapi juga kesempatan untuk mendapatkan kembali PR yang ideal (yakni membangun dan mempertahankan hubungan) dan mengubah sejumlah stereotype negatif khususnya yang terkait dengan keberadaan perusahaan. Media sosial membantu praktisi PR dalam komunikasi korporasinya untuk membangun dan mempertahankan hubungan dengan semua publik-pubilknya, bahkan termasuk jurnalis. Karena di masa sekarang ini, setiap orang terlalu sibuk dengan aktivitasnya, sehingga media sosial memungkinkan para praktisi PR untuk mempertahankan hubungan yang ada dan berkualitas dengan para pemangku kepentingan, media, konsumen, dan partner kerja tanpa memandang di manapun mereka berada. Media sosial juga bisa membantu meningkatkan hubungan komunitas, sebagaimana yang dinyatakan oleh Duhé (2012), social media, more, so than new/digital media, must be at the heart of public relations activities because social media can enchance organisation-public relationships by increasing and improving community relations.

PR merupakan sebuah pekerjaan yang telah cukup lama bergantung pada taktik dan formula yang sama dalam sejarah keberadaaanya, dan selama ini keberhasilannya secara tradisional diukur melalui jumlah liputan media yang dihasilkan dari output pesan-pesan yang dikeluarkan oleh perusahaan. Kehadiran media sosial kemudian secara cepat mengubah cara kampanye atau program PR, disebarkan dan dievaluasi. Daripada penggunaan metode tradisional tentang output perusahaan di mana pesan yang disebarkan kepada para pemangku kepentingan dikontrol oleh perusahaan secara menyeluruh. Media sosial mendorong komunikasi korporat untuk beralih pada penggunaan dialog di mana para pemangku kepentingan (dan bukan hanya perusahaan) memiliki kekuataan yang sama terhadap pesan yang bergulir. Media sosial memungkinkan para pemangku kepentingan untuk mengajukan pertanyaan dan mendapatkan jawaban atas pertanyaan tersebut secara langsung dari jajaran eksekutif perusahaan, dan di lain pihak bagi para eksekutif perusahaan menerima feedback penting dan bahkan gagasan dari para pemangku kepentingan mereka (Mangold \& Faulds, 2009).

Selain itu, media sosial juga bisa digunakan untuk memperdayakan konsumen dan internal perusahaan dengan 
memberi mereka kekuatan untuk mengekspresikan pandangan atau opini mereka mengenai sebuah produk atau pelayanan dengan bebas ke jaringan mereka. Sebagaimana yang dibenarkan oleh Tilley (2011) bahwa piramida kekuasaan telah bergeser dan konsumen serta pegawai yang di era sebelumnya berada di bagian dasar piramida dan menjadi pihak yang bisa memberikan pengaruh baru di dalam jaringan kelompok sesamanya. Oleh karena itu, jika sebuah perusahaan tidak berpartisipasi dalam riuhnya media sosial, maka bisa dipastikan bahwa mereka akan kehilangan banyak kesempatan, sebagaimana konsumennya telah menyebarkan pesan mengenai perusahaan, yang terkadang bisa saja berupa pesan yang merusak merek perusahan tersebut (Seiple, 2010). Di masa sekarang ini, reputasi, citra, kesuksesan, dan kegagalan sebuah perusahaan tergantung pada citra yang dibangun oleh perusahaan salah satunya melalui media sosial. Oleh sebab itu artikel ini dapat membantu mempertajam pemahaman mengenai pentingnya penggunaan media sosial secara tepat dalam komunikasi korporat mengingat ruang digital saat ini berpengaruh besar terhadap konstruksi identitas dan citra korporat serta positioning suatu perusahaan di antara kompetitornya. Karena bagaimanapun masa depan PR dan komunikasi korporat tergantung pada seberapa baik para profesionl tersebut belajar dan beradaptasi dengan kehadiran dan praktik teknologi baru. Artikel ini bertujuan untuk menelaah hubungan antara media sosial dengan komunikasi korporat, khususnya terkait dengan penggunaan media sosial bagi public relations $(\mathrm{PR})$ dan menganalisis perubahaan-perubahaan yang terjadi dalam industri masa kini sebagai akibat kehadiran media sosial.

\section{LANDASAN KONSEP}

Sejumlah penelitian telah dilakukan untuk menelaah peralihan dari praktik tradisional PR di era sosial media. Sebagian besar penelitian tersebut menjawab seperangkat pertanyaan umum terkait dengan penggunaan media sosial dalam komunikasi korporat, termasuk bentuk yang paling umum pemasaran media sosial, komitmen waktu yang diperlukan oleh para pemasar media sosial, manfaat pemasaran media sosial, audiens yang dapat dijangkau oleh pemasar media sosial, bagaimana efektivitas komunikasi diukur dalam pemasaran media sosial dan dampak pemasaran media sosial di masa mendatang.

Sebuah survei online yang melibatkan 5.086 partisipan yang dilaksanakan pada bulan Mei 2016 lalu oleh pemasar media sosial Michael Stelzner, menyebutkan bahwa sebagian besar partisipan adalah mereka yang menggunakan pemasaran media sosial sampai pada titik tertentu, dan penelitian tersebut mencoba mengungkap 'who, what, when, where and why' menggunakan pemasaran media sosial (Stelzner, 2016) sebagai salah satu strategi dalam komunikasi korporat mereka. Dalam laporan yang berjudul Social Media Marketing Industry Report: How Marketers Are Using Social Media to Grow Their Businesses, Stelzner memberikan pertanyaan atas lima media sosial paling top kepada para praktisi pemasaran, komitmen waktu dan manfaat pemasaran media sosial, media sosial yang paling umum digunakan, media sosial yang para praktisi tersebut ingin pelajari lebih jauh lagi, serta analisis tambahan mengenai informasi demografis (Stelzner, 2016).

Media sosial merupakan inovasi yang relatif terus berkembang, dan pemasaran media sosial merupakan industri yang relatif terus bergerak dinamis. Dari lebih 5.000 responden yang disurvei, sebagian besar para pemasar tersebut menyatakan bahwa penggunaan video merupakan hal yang sangat penting dalam aktivitas pemasaran mereka, dan menganggap bahwa penggunaan live video seperti facebook five dan periscope harus lebih ditingkatkan lagi (Stelzner, 2016). Setidaknya 63\% dari para pemasar tersebut berencana meningkatkan 
penggunaan jaringan media sosial mereka, di mana snapchat termasuk dalam rencana ke depan mereka selain facebook dan YouTube karena masih sangat sedikit sekali yang menggunakannya (5\%). Ketika diberi pertanyaan mengenai platform media sosial yang paling penting digunakan saat ini, 55\% pemasar tersebut menjawab facebook, dan diikuti dengan linkedln sebesar $18 \%$. Namun demikian, sekitar $40 \%$ responden menyatakan tidak mengetahui jika trafik yang dimiliki facebook telah mengalami penurunan selama setahun terakhir dan lebih dari sepertiga pemasar menyatakan tidak yakin jika pemasaran melalui facebook merupakan hal yang cukup efektif meskipun mayoritas di antara mereka secara reguler menggunakan iklan di facebook, dan sisanya lebih memilih menggunakan twitter. Para praktisi pemasaran yang disurvei dalam penelitian Stelzner tersebut mayoritas menyatakan ingin lebih mempelajari taktik sosial yang paling efektif dan cara terbaik untuk melibatkan audiens mereka dengan media sosial (Stelzner, 2016).

Survei tersebut mengindikasikan bahwa mayoritas partisipan sangat ingin tahu taktik sosial terbaik mengingat perubahan yang konstan terjadi dalam berbagai jejaring sosial, karena saat ini keterlibatan dengan konsumen menjadi keunggulan kompetitif yang terbilang unik. Selain itu, mayoritas pemasar ingin mempelajari bagaimana mengukur laba yang mereka dapat dari investasi yang mereka lakukan melalui aktivitas media sosial karena menemukan konsumen dan prospektif konsumen sendiri merupakan hal yang terus menjadi perhatian penting bagi mereka. Penelitian tersebut juga secara mengejutkan menemukan bahwa $86 \%$ di antara para responden tidak mengetahui media mana yang terbaik digunakan untuk memudahkan tugas mereka (Stelzner, 2016).

Dalam sebuah online survei yang dilakukan oleh PRSA, para praktisi PR diberi pertanyaan mengenai penggunaan mereka terhadap 18 media sosial yang ada serta persepsi mereka terhadap pertumbuhan kecederungan media sosial dalam praktik PR. Survei tersebut menemukan bahwa teknologi media sosial memungkinkan para praktisi PR 'to reach out to and engage their publics in conversation ... and provides an avenue to strengthen media relations, ' dan mayoritas dari para praktisi tersebut merasa bahwa teknologi komunikasi seperti media sosial membuat pekerjaan mereka lebih mudah dan memungkinkan mereka untuk menjangkau audiens yang lebih luas dan memperlancar sirkulasi informasi yang beredar (Eyrich, Padman \& Sweetser, 2008). Rata-rata responden yang disurvei menggunakan enam dari 18 media sosial yang terdaftar, di mana surat elektronik atau $e$-mail yang merupakan media yang telah paling lama ada digunakan paling banyak, diikuti dengan penggunaan intranet, blog, video konferensi serta podcast (Eyrich, Padman \& Sweetser, 2008).

Li dan Bernoff dalam bukunya yang berjudul Groundswell: Winning in a World Transformed by Social Technologies menelaah mengenai demografi audiens bagi pemasar media sosial. Kedua penulis menjelaskan istilah 'groundswell' yang ada dalam bukunya sebagai gerakan spontan masyarakat menggunakan sarana online untuk menghubungkan, mengambilalih pengalaman mereka sendiri, dan mendapatkan apa yang mereka perlukan; seperti informasi, dukungan, gagasan, produk, dan daya tawar antara satu individu dengan individu lainnya ( $\mathrm{Li} \&$ Bernoff, 2011). Menurut Li dan Bernoff, dalam konteks ini, kondisi yang ada (groundswell) memberikan kontrol kepada konsumen dan bukan kepada perusahaan, sesuatu yang dikhawatirkan oleh banyak perusahaan tetapi sebenarnya merupakan peluang.

Di Indonesia sendiri, laporan dari $e$ marketer pada Januari 2016 lalu menggambarkan dinamisnya lansekap media sosial yang ada. Populasi masyarakat yang mendekati angka 260.000.000 orang, sepertiga di antaranya merupakan pengguna aktif internet yang diprediksi akan terus 
bertumbuh mencapai angka 110.000.000 pengguna di tahun 2019 seiring dengan laju pertumbuhan regulasi dan infrasturktur yang mengarah pada transformasi digital (Chaffey, 2016). Penelitian tersebut menemukan bahwa Indonesia selalu berada dalam peringkat 10 besar pengguna empat platform media sosial paling top di dunia, yakni peringkat enam tertinggi sebagai pengguna facebook, peringkat kesepuluh di dunia sebagai pengguna YouTube, peringkat pertama pengguna twitter dan $\mathrm{G}+$ (Chaffey, 2016). Seperti yang juga dilaporkan oleh Loras (2016) maka dapat dibayangkan begitu cintanya masyarakat Indonesia dengan media sosial, bukan hanya untuk melakukan komunikasi sosial tetapi juga sebagai bagian dari strategi e-commerce bagi industri kecil (juga melalui WhatsApp, line, instagram, dan path) di mana lebih dari $90 \%$ penggunanya berusia di bawah 34 tahun.

Semua kajian terkait dengan media sosial dan komunikasi korporat melaporkan temuan yang serupa. Seiring dengan informasi demografis baik itu untuk para praktisi maupun audiens adalah gagasan mengenai konten tidak lagi secara eksekutif dikontrol oleh para profesional; di mana komunikasi korporat bergerak dari output murni ke arah dialog, serta para praktisi PR tradisional terus berusaha menggali penggunaan media sosial untuk pemasaran meskipun masih mempertanyakan dan mengawatirkan tentang cara yang tepat untuk menginfiltrasi pasar yang tumbuh dengan pesat.

\section{METODE PENELITIAN}

Artikel ini ditulis dengan menggunakan paradigma kualitatif dengan menekankan pada pendekatan analisis kritis. Data dikumpulkan dari kajian-kajian penelitian, publikasi, teknologi online, studi kasus, kecenderungan terkini mengenai teori dan literatur akademik terkait dengan praktik komunikasi korporat dan penggunaan media sosial yang ada. Data- data yang ditemukan oleh penulis kemudian dianalis dengan menggunakan teknik interpretatif yang bertujuan untuk memantaskan aspek PR tradisional dengan aspek PR pengguna media sosial, dan melalui perbandingan tersebut menganalisis perubahan yang terjadi dalam perusahaan serta mencoba memroyeksikan apa yang terjadi di masa mendatang.

\section{HASIL PENELITIAN DAN PEMBAHASAN}

\section{Analisis Public Relations Tradisional}

Jejak asal muasal PR kembali pada saat publisitas, promosi, dan propaganda yang berlebihan serta seringkali diasosiasikan dengan persepsi dan stereotipe negatif. Sejarah kampanye yang menyesatkan dan praktik-praktik tidak etis kembali kepada pendiri PR, yakni Edward Bernays. Bernays merupakan pioner praktik PR, namun praktik yang dilakukannya mendukung adanya manipulasi opini publik dan trend pemikiran seperti inilah yang banyak mendominasi praktik-praktik PR dalam sebagian besar sejarah industri PR (Lomasky, 1997).

Pada tahun 2000 lalu sebuah survei terkait permasalahan etika profesional PR yang dilakukan oleh PR Week mengindikasikan bahwa manipulasi kebenaran dalam PR merupakan hal yang tidak bisa ditinggalkan dalam keseharian propaganda PR yang tidak mengenal kata malu. Survei tersebut menemukan bahwa satu dari empat pekerja PR profesional mengakui kebohongan yang dilakukan dalam pekerjaan tersebut dan $39 \%$ lainnya mengakui telah 'melebih-lebihkan kebenaran yang ada'. Secara keseluruhan, $64 \%$ dari responden yang disurvei mengakui telah berbohong atau melebihlebihkan kebenaran dalam profesi yang mereka lakukan. Selain itu, jawaban atas pertanyaan yang lainnya mengungkap bahwa $44 \%$ responden menyatakan bahwa terkadang ada saat ketika mereka merasa 
tidak yakin mengenai etika pekerjaan diminta untuk dilakukan (Turney, 1998).

Survei lainnya yang pernah dilakukan oleh University of Pretoria (Comcowich, 2015) menyatakan bahwa 17 dari 20 eksekutif PR yang diwawancara mengakui sering berbohong kepada media, dan 16 di antaranya mengatakan kemungkinan akan melakukan hal yang sama di masa mendatang karena hal tersebutlah yang harus dilakukan demi nama baik perusahaan.

Kecenderungan PR sebagai bagian dari promosi dan propaganda yang berlebihan menyebabkan PR menjadi identik dengan istilah 'spin' dan 'flack' (Edson, 2006). Teknik-teknik manipulatif tersebut menyebabkan timbulnya rasa ketidakpercayaan dalam perusahaan dan media, meskipun seringkali mengalami keberhasilan karena secara tradisional, praktik-praktik komunikasi korporat ditandai oleh output yang teramat sangat dikontrol dan bersifat satu arah. Hal ini dikarenakan adanya instruksi otoritatif tentang 'staying on message' untuk memastikan bahwa perusahaan atau organisasi memiliki kontrol penuh atas pesan yang beredar setiap saat, yang secara virtual menyatakan kepada konsumen atau para pemangku kepentingan tentang apa yang harus dipikirkan atau dirasakan mengenai pesan yang dikomunikasikan (Stoker \& Rawlins, 2010).

Para ahli PR terkemuka, James Grunig dan Todd Hunt menguraikan empat model PR yang secara tradisional dipraktikkan oleh organisasi, yakni: agen pemberitaan (press agentry), informasi publik (public information), asimetris dua arah (two-way asymmetrical), dan simetris dua arah (two-way symmetrical). Model agen pemberitaan menjelaskan mengenai program PR dengan tujuan satu-satunya adalah menarik publisitas yang positif bagi organisasi dengan menggunakan media massa. Salah satu contoh paling awal mengenai model PR agen pemberitaan adalah pemilik sirkus Amerika, Phineas T. Barnum (Laskin, 2009). Pria yang terkenal menciptakan istilah 'There's sucker born every minute,' yang dikenal karena manipulasinya kepada media untuk mendapatkan publisitas (Frankel, 2005). Model informasi publik, mirip seperti model agen pemberitaan merupakan model komunikasi satu arah yang menggunakan 'journalists-in-residence' untuk menyebarkan informasi kepada media. Sedangkan model asimetris dua arah menggunakan riset untuk mengembangkan pesan yang dimungkinkan untuk membujuk target audiens untuk berperilaku sebagaimana yang diinginkan organisasi (Grunig, 2011).

Model keempat PR yang diperkenalkan oleh Hunt dan Grunig adalah model simetris dua arah. Model ini berdasarkan pada riset dan menggunakan komunikasi untuk mengelola konflik dan meningkatkan pemahaman dengan publik yang strategis. Model simetris dua arah merupakan model yang bersifat saling menguntungkan berdasarkan pada negasi dan kompromi, serta dipraktikkan oleh organisasi yang memahami pentingnya mendengarkan dan merespon publiknya (Grunig, 2011). Model ini merupakan model yang ideal bagi kesuksesan komunikasi korporat yang mengindikasikan bahwa organisasi berkomitmen untuk menjaga kejujuran dan praktik etisnya, serta memiliki keinginan untuk mengadaptasikan praktiknya untuk meningkatkan persepsi publik.

Kampanye dan program PR menggunakan strategi yang kurang lebih sama dalam sejarah profesinya dan secara umum berdasarkan pada sejumlah variasi fomula RACE yang dikembangkan oleh ahli komunikasi, Profesor John Marston (Bégin, 2013). RACE, merupakan akronim dari research, action, communication, dan evaluation yang merupakan alat perencanaan komunikasi yang digunakan para praktisi untuk mengembangkan kampanye atau program PR. Ketika menggunakan RACE atau variasi dari langkah-langkah yang serupa dengan model tersebut dalam mengembangkan kampanye 
PR, maka fase penelitian (research) umumnya melibatkan kegiatan survei atau pengujian kelompok yang terfokus dari target audiens; fase tindakan (action) yang meliputi perencanaan pesan dan pengirimannya; fase komunikasi (communication) yang meliputi penyebaran pesan yang umumnya menggunakan media tradisional seperti televisi, radio, atau media cetak; serta fase evaluasi komunikasi yang diukur dengan melakukan kuantifikasi media yang memuat pesan tersebut (Grunig, 2011).

\section{Analisis Penggunaan Media Sosial oleh PR}

Mayoritas netizen di dunia saat ini mengalami apa yang disebut sebagai kecanduan dengan kehadiran media sosial. Dengan lebih 1,49 miliar pengguna facebook, 850 miliar anggota dari berbagai grup di facebook, 380 miliar pengguna linkedln, dan 304 miliar pengguna twitter (Statista, 2015), jelas kiranya bahwa masa depan media sosial sangatlah cerah. Oleh karena itu, perusahaan harus menggunakan fitur-fitur yang berguna di media sosial untuk keperluan komunikasi korporatnya atau mereka akan tertinggal di belakang sementara para pesaingnya mencuri perhatian secara online.

Pemasaran melalui media sosial merupakan alat komunikasi yang revolusioner yang dengan cepat mengubah cara di mana praktik PR dilakukan dengan menjadi bagian integral dari komunikasi korporat bagi banyak perusahaan. Media sosial menawarkan para praktisi PR pilihan baru untuk setiap aspek proses komunikasi korporat. Dari fase riset sampai dengan evaluasi di mana media sosial dapat digunakan untuk menciptakan dan mendistribusikan konten dengan makna pesan tertentu kepada audiens yang lebih luas daripada yang diberikan oleh media tradisional.

Video yang berjudul 'Social Media Revolution-Did You Know' yang dibuat oleh Qualman (2016), yang merupakan penulis blog media sosial yang bernama
Socialnomics dan buku dengan judul yang sama, termasuk sejumlah statistik mengenai media sosial yang luar biasa; menggambarkan bagaimana media sosial sebagai media yang sangat luar biasa dapat menjadi dan memberi indikasi tentang caracara yang dapat digunakan oleh para praktisi PR untuk memaksimalkan praktik kerjanya.

Sejak kebangkitan perkembangan media sosial, PR secara luas menjadi divisi yang bertanggungjawab terhadap pengelolaan dan mempertahankan keberadaan media sosial perusahaan yang mengepalai divisi pemasaran dan lainnya dalam mengadopsi platform tersebut. Menurut 2009 Digital Readiness Report berdasarkan jawaban survei kepada 278 praktisi PR, Pemasaran dan Sumber Daya Manusia (SDM) menemukan bahwa, 'Public Relations is leading the social media revolution inside organisations of all types and sizes' (Schwartzman, Smith, Spetner, et al., 2009). Menurut laporan tersebut:

- PR memimpin divisi pemasaran dalam mengelola semua saluran komunikasi media sosial.

- $51 \%$ dari seluruh organisasi yang disurvei menyatakan bahwa PR memimpin aktivitas komunikasi digital yang dilaksanakan.

- PR bertanggungjawab untuk pengelolaan website pada $49 \%$ organisasi yang disurvei, dan bertanggungjawab terhadap jejaring sosial pada $48 \%$ organisasi tersebut.

- PR bertanggungjawab terhadap aktivitas mikro-blogging pada 52\% organisasi yang menjadi objek survei. (Schwartzman, Smith, Spetner, et al., 2009).

Menurut ahli media sosial dan PR, Jason Falls, ' $P R$ has taken on an entirely new role in the organisation over the last two to three years. It's the most dramatic shift in the industry since the invention of email, but is happening faster and more dramatically' (Adi, 2013). 
Salah satu perubahan luar biasa dari kehadiran media sosial dalam komunikasi korporat telah mendorong penciptaan pekerjaan yang spesifik dengan media sosial. Menurut Richard Riley hal tersebut termasuk dalam 10 pekerjaan yang paling diminati pada tahun 2010 yang tidak ada pada tahun 2004 lalu (Eger, 2012). Perusahaan yang mempekerjakan praktisi PR tidak lagi puas dengan media perdagangan tradisional seperti rilis berita, sehingga para praktisi PR di era media sosial ini harus memiliki pemahaman mengenai bagaimana menggunakan media sosial dalam komunikasi korporat.

Menurut laporan Digital Readiness, ‘ When searching for prospective candidates, knowledge of social media is almost as important as traditional media relations skills' (Schwartzman, Smith, Spetner, et al., 2009). Menurut laporan tersebut:

- Di antara mereka yang bertanggungjawab untuk perekrutan pekerja PR dan pemasaran, $82 \%$ dari responden menyatakan keahlian hubungan media mainstream merupakan hal yang penting atau bahkan sangat penting. Lebih dari $80 \%$ menyebutkan pengetahuan tentang jejaring sosial juga merupakan hal yang penting atau sangat penting. Hampir 77\% menyebutkan jika pengetahuan mengenai menulis blog, podcasting, atau RSS (Really Simple Sindication) merupakan hal penting atau bahkan sangat penting, serta hampir $72 \%$ menyatakan pemahaman mengenai pelayanan mikro blogging seperti twitter adalah hal yang juga penting atau sangat penting.

- Kemampuan komunikasi media baru lainnya yang dianggap penting atau sangat penting oleh para pemberi pekerjaan adalah optimalisasi mesin pencari $(62 \%)$, pengelolaan email $(56 \%)$, pengelolaan isi web (52\%) serta bookmark sosial $(51 \%)$.

- Untuk memenuhi kebutuhan komunikasi internal dan eksternal perusahaan di masa sekarang ini, para pencari kerja di bidang PR atau pemasaran perlu untuk mengembangkan portofolio yang komprehensif mengenai kemampuan komunikasi digitalnya.

- $18 \%$ dari perusahaan tidak memiliki ketertarikan sama sekali lagi dengan semua kemampuan PR tradisional yang menandakan adanya pergesaran dari pendekatan yang berfokus pada media mainstream.

Perkembangan media sosial membawa dampak yang luar biasa terhadap profesi PR. Hal tersebut menawarkan kesempatan baru dan keahlian baru bagi keberhasilan praktik-praktik PR. Tekanan kebutuhan akan keahlian media sosial dalam profesi PR mendorong pada penciptaan karir baru, di mana para praktisi harus menyadari bagaimana pemasaran media sosial dapat digunakan bagi komunikasi korporat. Pemasaran media sosial merupakan media yang sangat efektif bagi profesi PR karena media tersebut menawarkan saluran baru bagi keberhasilan komunikasi yang diperlukan antara organisasi dengan publik-publiknya, serta kesempatan baru agar komunikasi tersebut menjadi lebih bermakna dan bermanfaat bagi kedua belah pihak.

Praktisi PR sebagian besar telah mengadopsi teknik-teknik pemasaran media sosial, sehingga aspek-aspek tradisional formula RACE juga berkembang. Meskipun prinsip dasarnya tetap sama, tetapi platform media sosial menawarkan para praktisi cara-cara baru untuk mengimplementasikan elemen-elemen tradisional tersebut ke dalam praktik PR. Fase riset yang merupakan tahapan krusial dalam perkembangan kampanye atau program PR, dan kehadiran media sosial menawarkan peluang baru bagaimana riset tersebut dapat dilaksanakan. Distribusi dan penerimaan survei misalnya dapat sangat terbantu melalui penggunaan media sosial dan menjadi alternatif bagi metode riset tradisional seperti misalnya diskusi kelompok terfokus, di mana para praktisi PR memiliki kesempatan untuk 
menyaksikan perbincangan yang terjadi antar pemangku kepentingan yang dilakukan dan mengimplementasikan temuan tersebut ke dalam kampanye yang akan dilaksanakan.

Kampanye PR di era media sosial harus beradaptasi dan menjadi lebih fleksibel lagi. Penerimaan oleh para pemangku kepentingan harus diperhitungkan secara terus menerus dalam pengembangan aktivitas kampanye PR, dan jika penerimaan berubah selama proses berlangsung maka kampanye tersebut harus diubah untuk mengakomodasi perubahanperubahan tersebut. Komunikasi yang dilakukan saat kampanye atau pelaksaan program PR, memiliki segudang pilihan penyebaran pesan. Sehingga PR tidak lagi sekedar membanjiri ruang berita dengan rilis berita dan pemberitahuan kepada media. Meskipun media tradisional masih sangat penting, tetapi para praktisi PR perlu mengetahui bagaimana mendesain pesannya yang diperuntukkan kepada audiens baru. Media sosial menawarkan kesempatan terciptanya siaran pemberitaan yang bersifat interaktif yang dapat diterima di berbagai website, untuk para blogger, daripada hanya sekedar kepada jurnalis. Tahap evaluasi juga mengalami perubahaan, di mana platform media sosial menawarkan peluang-peluang baru untuk mengukur efektivitas komunikasi. Keberhasilan kampanye atau program PR tidak lagi diukur hanya dengan beratnya klipping media cetak yang berhasil diperoleh, tetapi oleh sejumlah postingan blog, percakapan, komen, retweet, bookmark, dan lain sebagainya yang diperoleh secara online.

Pemasaran media sosial merupakan sarana ampuh yang sangat cocok menggambarkan pengadopsian model PR idealnya menurut Hunt dan Grunig, adalah model simetris dua arah (Laskin, 2009)'. Praktik PR yang dilakukan dengan berdasar pada output satu arah atau memanipulasi kebenaran tidak dapat bertahan di era media sosial ini. PR telah berubah, dan akan terus mengalami perubahan dengan menekankan praktik kerjanya yang lebih selaras dengan cita-cita profesi yang diembannya. Sederhananya, PR berkembang seiring dengan publik. Jika media sosial digunakan untuk memenuhi potensi terbaiknya bagi komunikasi korporat, maka profesi ini akan memiliki kesempatan untuk memperjuangkan idealismenya, serta melalui praktik kerja yang bersifat transparan dan jujur akan mampu mengimplementasikan kampanye yang sukses dan melawan stereotipe negatif yang sering diterimanya.

Penciptaan lapangan kerja baru berakibat pada perlunya keahlian-keahlian baru, yakni kemampuan yang saat ini belum diajarkan secara luas. Kebanyakan mahasiswa PR saat ini masih mempelajari format media tradisional seperti rilis pemberitaan, sehingga pergeseran kebutuhan harus hadir dalam dunia akademis untuk mengintegrasikan aspekaspek baru dalam profesi tersebut. Para praktisi PR perlu untuk mengetahui bagaimana menciptakan konten bagi para audiens baru, serta bagaimana menggunakan media sosial agar memiliki komunikasi yang lebih bermakna dengan publik organisasinya.

\section{Menghadapi Peluang dan Tantangan Media Sosial Untuk Komunikasi Korporat Efektif}

Penggunaan media sosial oleh suatu perusahaan tentunya di lain sisi juga melengkapi konsumen dengan hak bersuara dan sebuah platform yang memungkinkan memperdayakan kemampuan mereka untuk memperkuat dan juga menginformasikan pengambilan keputusannya akan sesuatu hal. Sifat keterhubungan yang dimiliki internet membuat segala opini dan pandangan yang dimiliki oleh para pemangku kepentingan bisa dibagi dengan mudahnya, dan aksesibilitas sarana media sosial membuat segalanya lebih mudah, terutama bagi para konsumen untuk menemukan berbagai opini dan tanggapan terkait satu produk atau layanan tertentu yang dimiliki oleh suatu perusahaan, dan 
kemudian memberikan respon serta membaginya lebih luas lagi. Semua hal tersebut berkontribusi terhadap persepsi sebuah merek atau citra suatu perusahaan. Oleh sebab itu, penting bagi praktisi PR untuk menunjukkan bahwa mereka benarbenar mendengarkan komen, complain, dan pertanyaan yang diajukan secara online oleh para pemangku kepentingan tersebut, sama seperti ketika berada dalam konteks komunikasi konvensional. Maka penting untuk memberikan komentar ketika hal tersebut memang pantas untuk dilakukan, mendengarkan dengan penuh ketertarikan, kesopanan, rasa hormat, dan memberikan penghargaan sebisa mungkin. Para praktisi PR yang mewakili merek suatu korporat harus bisa menjadi partisipan aktif dalam suatu percakapan yang berlangsung.

Perusahaan yang berhasil melakukan komunikasi yang efektif dengan audiensnya secara terus menerus harus mencari peluang untuk mendorong citra perusahaan ke garis terdepan, dan menjaga mata mereka untuk terus terbuka akan risiko yang mungkin saja mengancam keberadaan reputasi perusahaan. Dalam kedua situasi tersebut, kekuataan suatu perusahaan terletak pada bagaimana mereka memberikan respon terhadap situasi yang ada. Respon tersebut dapat berupa keterlibatan aktif sampai pada kampanye pemasaran baru. Pada akhirnya semua hal tersebut tergantung pada seberapa kuat kesempatan atau risiko yang dihadapi oleh suatu perusahaan.

Posisi yang harus dicapai komunikasi korporat melalui media sosial sebisa mungkin disebutkan secara positif di setiap kemungkinan yang ada. Jika hal tersebut bisa dicapai oleh PR maka artinya praktisi PR telah bekerja dengan luar biasa. Namun demikian, tidak berarti bahwa tidak ada lagi hal yang harus dilakukan. Selama masa tersebut, PR harus tetapi melakukan semua cara dengan segenap kemampuan yang dimilikinya untuk mendorong volume percakapan menjadi lebih tinggi lagi. Hal ini dikarenakan, para pemangku kepentingan bersikap positif terhadap suatu perusahaan dikarenakan ekspektasi yang mereka miliki melampaui apa yang ada. Namun sayangnya, harapan bisa selalu berubah dari waktu ke waktu. Oleh sebab itu perusahaan harus terus tetap bisa memosisikan diri mereka pada diri pemangku kepentingan dan secara terus menerus bersikap waspada akan cara yang baru dan inovatif untuk memenuhi dan mengembangkan janji yang diusung oleh perusahaan.

Namun bagaimana jika yang terjadi adalah semua hal yang diperbincangkan terkait perusahaan, apakah perusahaan tetap bersifat netral atau biasa saja? Jika kasus ini yang terjadi, maka penting bagi perusahaan untuk bersikap mawas diri karena artinya bisa saja perusahaan memiliki citra yang membosankan, atau tidak dalam posisi yang baik untuk mendapatkan perhatian para pemangku kepentingan. Sebagaimana yang dikatakan oleh Godin dalam Hall, Rodgers, Wilson, et al. (2010) bahwa 'safe is risky'. Jika suatu perusahaan memilih bermain aman di mana publiknya berada dalam kondisi tidak ingin memberikan pujian maupun kritikan, maka diperkirakan perusahaan berada dalam posisi berbahaya yang membuatnya bisa dengan mudah dilupakan. Karena tahapan berikutnya adalah tidak ada seorangpun yang akan berbicara sama sekali mengenai produk atau layanan yang dimiliki perusahaan tersebut. Lantas bagaimana jika perusahaan mendapatkan perbincangan yang bersifat negatif? Bagi praktisi PR pernyataan negatif harus dipahami sebagai janji mereka yang tidak bisa ditepati oleh perusahaan. Hal ini harus dianggap sebagai lemahnya kinerja yang dilakukan perusahaan yang berada di bawah ekspektasi yang seharusnya, sehingga harus ditangani sebagai masalah dengan skala prioritas tinggi. Selama masa ini, perusahaan harus berhati-hati untuk tidak membangkitkan perbincangan yang dianggap tidak perlu atau bermanfaat bagi kebangkitan citra perusahaan. Meskipun hal tersebut tidak serta merta merupakan malapetaka bagi perusahaan. Jika perbincangan yang bersifat negatif tersebut meluas, hal tersebut biasanya disebabkan 
oleh adanya sejumlah permasalahan mendasar lainnya yang tersimpan selama ini, dan hal ini seharusnya menjadi sumber informasi bagi perusahaan untuk menyelesaikan dengan seksama. Keluhan yang berasal dari para pemangku kepentingan yang memiliki hubungan dengan perusahaan berarti perusahaan belum bisa memenuhi harapan mereka. Dengan memberikan keluhan artinya publik tersebut, tanpa disadari, memberikan perusahaan kesempatan untuk membenarkan hal yang dianggap kurang atau salah, dan menunjukkan bahwa perusahaan sebenarnya bisa meningkatkan hal tersebut.

Jika complain tersebut dilakukan secara online, maka resolusi yang harus diberikan oleh perusahaan juga harus menggunakan media tersebut, meskipun PR juga bisa mencoba melakukannya dalam konteks offline. Meskipun respon yang diberikan bisa berupa email atau telepon, namun postingan melalui media sosial bisa menunjukkan secara masif kepada publik bahwa perusahaan mendengarkan, merespon, dan menanggapi kritik yang diberikan secara objektif demi menyelesaikan masalah yang ada. Kritikan tidak serta merta selalu datang dari konsumen, tetapi penting kiranya untuk bersikap waspada dengan hal tersebut. Terutama jika kritikan sudah melibatkan informasi palsu, maka hal tersebut haruslah dikoreksi dengan cepat. Jika kritikan tersebut merupakan hal yang benar, maka perusahaan harus dengan sigap menangani hal tersebut.

\section{PENUTUP}

\section{Simpulan}

Pergeseran paradigma profesi PR dari praktik komunikasi korporat yang bersifat tradisional ke arah penggunaan media sosial merupakan hal yang baru di masa sekarang ini. Kecepatan yang mengakibatkan pergeseran tersebut hadir dan mendorong terjadinya perpecahan dalam profesi $\mathrm{PR}$, yang memisahkan mereka sebagai pengadopsi awal dengan mereka yang terlalu lamban masuk dalam era media sosial. Bagaimana perusahaan merespon perkembangan media sosial ini merupakan indikator keberhasilan di masa depan. Perusahaan yang terlalu lamban mengadopsi teknologi dan praktik-praktik baru tersebut akan tertinggal di belakang. Karena saat ini, konsumen saling berkomunikasi satu sama lain dengan menggunakan media sosial.

Media sosial akan terus berkembang dan mengalami perubahaan, serta praktikpraktik komunikasi korporat akan terus berubah seiring dengan hal tersebut. Media sosial telah membuktikan diri sebagai media yang sangat berharga bagi profesi PR, sehingga PR bisa mengimplementasikan lebih luas lagi penggunaan media tersebut. Kemunculan media sosial mengakibatkan terjadinya perkembangan yang luar biasa terhadap komunikasi korporat. Dari praktik-praktik tradisional yang selalu sama, profesi PR berkembang secara cepat mengakomodasi perubahan yang terus terjadi dan kehadiran media baru, sehingga menciptakan peluang bagi hadirnya komunikasi yang lebih bermakna, demi keberhasilan kampanye dan mewujudkan idealisme profesi PR. Penting bagi perusahaan untuk mengenali pemangku kepentingannya, dan bukan sebaliknya. Mengabaikan hal tersebut bisa jadi akan berakibat perusahaan kehilangan pelanggan strategisnya.

\section{Saran}

Mengingat mayoritas penduduk dunia saat ini telah terhubung bahkan sampai batas tertentu mengalami kecanduan dengan keberadaan sosial media, seperti facebook, linkedln, twitter, dan lain sebagainya; maka perusahaan bisa menggunakan berbagai fitur penting yang dimiliki oleh media sosial tersebut dalam praktik komunikasi korporat.

Semua perusahaan perlu mengintegrasikan media sosial dengan menyelaraskan penggunaannya dengan 
cita-cita dan filosofi perusahaan guna menuai manfaat dari media sosial.

Media sosial adalah masa depan; sehingga para profesional PR harus mampu memanfaatkan media ini untuk keperluan komunikasi korporat dan kampanye perusahaan. Kampanye media sosial dapat meningkatkan citra perusahaan di mata semua pemangku kepentingan. Bagi praktisi PR perlu melakukan riset komunikasi dan memadukan strategi komunikasi korporatnya dengan para pemangku kepentingan tersebut, dan bukanlah sebaliknya.

\section{DAFTAR PUSTAKA}

Adi, A. (2013) Social Media Audit and Analytics. In: Social Media and the New Academic Environment. [Online]. IGI Global. pp. 143-162. Available from: doi:10.4018/978-1-4666-2851-9.ch007.

Bégin, D. (2013) Rethinking the R.A.C.E. model for a social media world. Journal of Professional Communication. [Online] 2 (2). Available from: doi:10.15173/jpc.v2i2.129.

Chaffey, D. (2016) Global social media research summary 2016. [Online]. Available from: http://www.smartinsights.com/social-med ia-marketing/social-media-strategy/new-g lobal-social-media-research/ [Accessed: 25 December 2016].

Comcowich, W. (2015) Dueling Surveys: Are PR Pros Ethical or a Bunch of Liars? [Online]. 2015. Available from: http://www.cyberalert.com/blog/index.ph p/dueling-surveys-are-pr-pros-ethical-ora-bunch-of-liars/ [Accessed: 25 December 2016].

Davidson, L. (2015) Is your daily social media usage higher than average? - Telegraph. [Online]. 2015. The Telegraph. Available from:

http://www.telegraph.co.uk/finance/news bysector/mediatechnologyandtelecoms/11 610959/Is-your-daily-social-media-usagehigher-than-average.html.

Dilenschneider, R.L. (1998) 'Spin Doctors' Practice Public Relations Quackery WSJ. [Online]. 1998. The Wall Street
Journal. Available from: https://www.wsj.com/articles/SB8966426 93373854500.

Duhé, S.C. (2012) New Media and Public Relations. [Online]. Peter Lang. Available from:

https://books.google.com/books?id=n6hy FnSRkEwC\&pgis $=1$.

Edson, A.S. (2006) Flak vs. Flack: That Is the Question. Cheklist. [Online]. pp.30-31. Available from: http://www.edsonpr.com/NEWS/Cheklist _summer06.pdf.

Eger, J.M. (2012) It's All About Creativity. [Online]. 2012. The Huffington Post. Available from: http://www.huffingtonpost.com/john-meger/-its-all-aboutcreativity_b_1358886.html.

Eyrich, N., Padman, M.L. \& Sweetser, K.D. (2008) PR practitioners' use of social media tools and communication technology. Public Relations Review. [Online] 34 (4), 412-414. Available from: doi:10.1016/j.pubrev.2008.09.010.

Frankel, T. (2005) Trust and Honesty: America's Business Culture at a Crossroad. Oxford University Press.

Grunig, J.E. (2011) Public relations and strategic management: Institutionalizing organization-public relationships in contemporary society. Central European Journal of Communication. [Online] 4 (1(6)), 11-31. Available from: http://cejsh.icm.edu.pl/cejsh/element/bw meta1.element.desklight-69a525a7-ea714b47-981d-31fa059ad02a.

Hall, C.R., Rodgers, W.M., Wilson, P.M. \& Norman, P. (2010) Imagery Use and SelfDetermined Motivations in a Community Sample of Exercisers and Non-Exercisers. Journal of Applied Social Psychology. [Online] 40 (1), 135-152. Available from: doi:10.1111/j.1559-1816.2009.00566.x.

Laskin, A. V. (2009) The evolution of models of public relations: an outsider's perspective. Journal of Communication Management. [Online] 13 (1), 37-54. Available from: doi:10.1108/13632540910931382

[Accessed: 25 September 2015].

Li, C. \& Bernoff, J. (2011) Groundswell: Winning in a World Transformed by Social Technologies. Boston, Harvard Business Review Press. 
Lomasky, L.E. (1997) What Do People Really Want? Timur Kuran's 'Private Truths, Public Lies'. The Independent Review. [Online] 1 (3), 413-421. Available from: http://www.jstor.org/stable/24561104.

Loras, S. (2016) Social media in Indonesia: big numbers with plenty of room to grow. [Online]. 2016. ClickZ. Available from: https://www.clickz.com/social-media-inindonesia-big-numbers-with-plenty-ofroom-to-grow/94062/ [Accessed: 25 December 2016].

Mangold, W.G. \& Faulds, D.J. (2009) Social media: The new hybrid element of the promotion mix. Business Horizons. [Online] 52 (4), 357-365. Available from: doi:10.1016/j.bushor.2009.03.002.

Michel, A.I.G., Ruggiero, T.E. \& Yang, K.C.C. (2016) How Public Relations Practitioners Perceive Social Media Platforms? In: Punita Duhan \& Anurag Singh (eds.). Managing Public Relations and Brand Image through Social Media. [Online]. IGI Global. pp. 1-19. Available from: doi:10.4018/978-1-5225-0332-3.ch001.

Patrut, M. \& Patrut, B. (2013) Social Media in Higher Education: Teaching in Web 2.0. 1 st edition. Hershey, PA, USA, IGI Global.

Qualman, E. (2016) Social Media Revolution Did You Know. [Online]. 2016. Available from:

https://www.youtube.com/watch?v=odoY OuvwjDE.

Rohampton, J. (2017) 5 Social Media Trends That Will Dominate 2017. [Online]. 2017. Forbes. Available from: https://www.forbes.com/sites/jimmyroha mpton/2017/01/03/5-social-media-trendsthat-will-dominate-2017/\#1c2aa96b6ffe.

Schwartzman, E., Smith, T., Spetner, D. \& McDonald, B. (2009) Essential Online Public Relations and Marketing Skills. 2009 Digital Readiness Report Essential.

Seiple, P. (2010) How to Leverage Social Media for Public Relations Success Using Social Media to Generate Media Coverage and Improve Brand Sentiment. [Online]. HubSpot. Available from: https://cdn2.hubspot.net/hub/53/file13204195pdf/docs/hubspot_social_media_pr_eboo k.pdf.

Statista (2015) Number of monthly active Twitter users worldwide from 1st quarter 2010 to 1st quarter 2017 (in millions). [Online]. 2015. Statista. Available from: https://www.statista.com/statistics/28208 7/number-of-monthly-active-twitterusers/ [Accessed: 25 December 2016].

Stelzner, M.A. (2016) 2016 Social Media marketing Industry Report: How Marketers Are Using Social Media to Grow Their Businesses. [Online]. Available from: http://www.socialmediaexaminer.com/soc ial-media-marketing-industry-report2016/.

Stoker, K. \& Rawlins, B. (2010) Taking the BS out of PR: Creating genuine messages by emphasising character and authenticity. Ethical Space: The International Journal of Communication Ethics. [Online] 7 (2/3), 61-69. Available from: http://www.communicationethics.net/jour $\mathrm{nal} / \mathrm{v} 7 \mathrm{n} 2-3 / \mathrm{v} 7 \mathrm{n} 2-3$ _feat1.pdf.

Tilley, E. (2011) New Culture/Old Ethics: What Technological Determinism Can Teach Us About New Media. In: Bruce E. Drushel \& Kathleen German (eds.). The Ethics of Emerging Media: Information, Social Norms and New Media Technology. New York, The Continuum International Publishing Group. pp. 191-212.

Turney, M. (1998) Explanatory phase of public relations. [Online]. 1998. Available from: https://www.nku.edu/ turney/prclass/read ings/3eras2.html. 